\title{
Current knowledge and breeding perspectives for the miracle plant Synsepalum dulcificum (Schum. et Thonn.) Daniell
}

\author{
Enoch G. Achigan-Dako • Dèdéou
}

A. Tchokponhoué · Sognigbé N'Danikou •

Jens Gebauer • Raymond S. Vodouhè

Received: 22 August 2014/Accepted: 5 February 2015/Published online: 18 February 2015

(C) Springer Science+Business Media Dordrecht 2015

\begin{abstract}
Synsepalum dulcificum, an African native shrub, is a valuable species. All plant parts are of medicinal importance whereas the fruit known as magic berry, miracle berry, or sweet berry is consumed fresh. Surprisingly, very little is known on the species in terms of genotypes utilization and breeding. In this review we recalled the uses and importance of the species and suggested research avenues for an accelerated growth and fruit production. Synsepalum dulcificum is rich in glycoprotein and is an excellent natural sweetener and also a good candidate for the synthesis of drugs against diabetes. Furthermore, $S$. dulcificum has high content in phytochemical substances (e.g. (+)-epi-syringaresinol, vanillic acid, cyanidin-3-monogalactoside, and quercetin-3-monogalactoside) with various health and food benefits. Data on the nutrient content are limited. Likewise,
\end{abstract}

E. G. Achigan-Dako $(\bowtie) \cdot$ D. A. Tchokponhoué . S. N'Danikou

Horticulture and Genetics Unit, Faculty of Agronomic

Sciences, University of Abomey-Calavi,

01 BP 526, Cotonou, Republic of Benin

e-mail: enoch.achigandako@uac.bj

S. N'Danikou · R. S. Vodouhè

Bioversity International, West and Central Africa Office, 08 BP 0932, Cotonou, Republic of Benin

J. Gebauer

Faculty of Life Sciences, Rhine-Waal University of Applied Sciences, Marie-Curie-Straße 1, 47533 Kleve, Germany knowledge on the reproductive biology and mating system is still narrow, combined with poorly developed horticultural practices. To fully exploit the potential of $S$. dulcificum prospective actions include: (1) improving the propagation and growth abilities of the species, (2) improving knowledge of floral biology and genetic diversity, (3) understanding the phenological phases of the species, gene expressions and how this contributes to metabolites accumulation and (4) improving genotypes for beverages, cosmetics and pharmaceutical industries and other value chains.

Keywords Beverage and drug industries .

Glycoproteins · Horticulture - Indigenous fruit · Plant selection · Synsepalum dulcificum

\section{Introduction}

Synsepalum dulcificum (Schum. et Thonn.) Daniell is a very promising species but unfortunately poorly documented resource. The species is well known for its taste modifying property. That property has been traditionally exploited since centuries in Africa. For instance, in Benin the miracle fruit helped local people consume tart or sour foods. In Ghana, the species was integrated in local dishes and preparation of beverages (Pieniazek 1976). Overall, the miracle fruit was used to sweeten acidulated maize bread, palm wine, and local beer (Inglett and May 1968). S. dulcificum is rich 
in anthocyanin and was reported to have good potential in food industries. Modern utilizations of the taste modifying property of the pulp and pigments of the peel (outer cover) have emerged with the development of food industries (Buckmire and Francis 1978). S. dulcificum exhibits a high color changing ability that is twice that of FD\&C Red No. 2 (a product used in food formulation). Anthocyanin pigments from the species offer a good stability to carbonated beverages, especially at cool temperature when it comes to long-term storage (Buckmire and Francis 1978). S. dulcificum also has many applications in folk medicine and is used either raw or processed (e.g. powder, infusion, or decoction). In Benin, the fresh leaves are involved in the treatment of diabetes, malaria, hyperthermia; and enuresis whereas the almond is used to treat stomachache, anemia, and obesity (Oumorou et al. 2010). Likewise, the root is used to treat cough and tuberculosis and the bark serves in prostate ailments treatment (Oumorou et al. 2010). The branches serve in the making of agricultural tools like hoe and rake whereas twigs are used as vegetal toothbrush (Oumorou et al. 2010).

For many economically important species, breeding has played a tremendous role in their potential use especially in terms of yield increase, resistance to abiotic and biotic stresses, growth cycle reduction, and the nutritional quality of the production. For instance, genetic bio-fortification has been a cost-effective (Stein et al. 2007) plant breeding technology used to improve zinc content in cereal grain (Cakmak 2008), and iron bioavailability and content in rice (Lucca et al. 2001). Likewise, Tiwari et al. (2010) revealed that substitutions of $2 \mathrm{~S}$ and $7 \mathrm{U}$ chromosomes of Aegilops kotschyi Boiss. in wheat are sufficient to enhance grain iron and zinc concentration. In the same line, many resistance and yield increase genes were identified from some crop wild relatives in Oryza genus and are actually exploited in rice production throughout introgression (Gaikwad et al. 2014). In Carica papaya L., in vitro culture of embryo resulted in a significant reduction in the species breeding cycle (Tamaki et al. 2011). This new knowledge could help reduce to 6 years the required time to produce new varieties of $C$. papaya instead of 15 years as reported by Ray (2002). Likewise, Jonkers (1958) has shortened a strawberry, Fragaria $\times$ anannassa Duch., lifecycle from 24 to 9 months by combining sulfuric acid treatment on seed and short day treatment on sensitive seedlings (seedlings receiving light from 8 a.m. to 4 p.m. during 6 weeks).

For S. dulcificum, an indigenous plant resource, knowledge on genetic improvement potential is still scanty and not much is known on how to develop improved varieties (e.g. early maturing lines, drought or short flood tolerant genotypes) to meet the increasing demand for the species and promote sustainable utilization. Moreover, little is known on how cropping the species (Idohou et al. 2013) has affected the conservation of wild stands (Bleasdale 1959) and genetic resources.

In this review we synthetize current knowledge on the species' reproductive biology, systematic, botany, genetic resources, biochemistry, and possible breeding avenues. We emphasize on ways to develop horticultural practices and breeding potential that reduce the fruiting cycle for increased production and utilizations with the expectation that this will increase scientific endeavours and help exploit the resource in a sustainable manner.

Species botany

\section{Description and systematics}

Synsepalum dulcificum, previously known as Bumelia dulcificum (Schumacher 1827) or Sideroxylon dulcificum (Candolle 1844), belongs to Sapotaceae, a large plant family with circa thirty to forty genera about which knowledge is still obscure. The genera Synsepalum is confined to tropical Africa and consists of about thirty species (African Plants Database version 3.4.0, 2013). In tropical West Africa, eight useful species were identified including Synsepalum afzelii (Engl.) Pennington, $S$. brevipes (Bak.) Pennington, $S$. cerasiferum (Welw.) Pennington, S. dulcificum (Schum. et Thonn.) Daniell, S. glycydorum Wernham, S. msolo (Engl.) Pennington, S. revolutum (Bak.) Pennington, S. stipulatum (Radlk.) Engl. (Burkill 2000). Out of those species, S. dulcificum is the most widely distributed, covering Ghana, Benin, Nigeria, Cameroun and Congo. In Benin, four species had been listed including $S$. dulcificum, S. glycydorum, $S$. brevipes and Synsepalum passargei (Engl.) T.D. Penn (Akoègninou et al. 2006). 

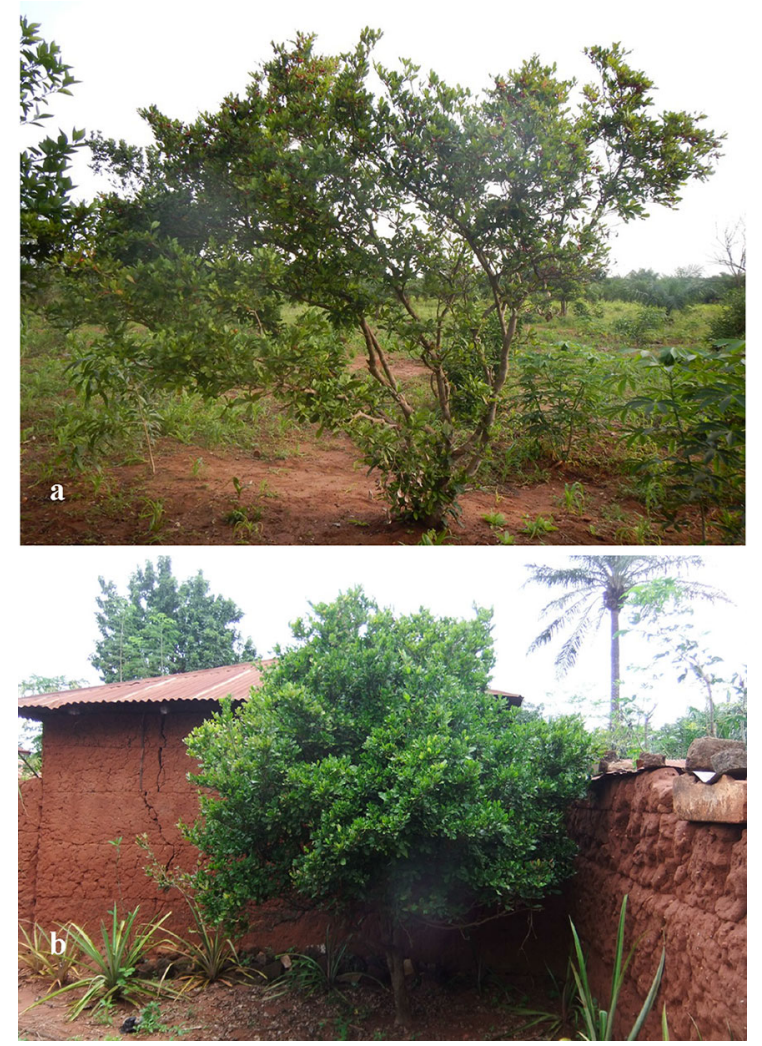

Fig. 1 Synsepalum dulcificum plants in Benin. a a shrub of about $3 \mathrm{~m}$ tall in a farm (Houéyogbé, Benin), b a shrub in home garden (Abomey, Benin)

Synsepalum dulcificum is an evergreen shrub reaching $4 \mathrm{~m}$ tall (Fig. 1a, b). Leaves are entire, alternate, symmetrical, and obovate-lanceolate to broadly lanceolate and pointed at apex, with $4.3-7.5 \mathrm{~cm}$ long and $3.1-3.8 \mathrm{~cm}$ in width. The length/width ratio is $2: 1$. The apex in itself is obtuse and is occasionally slightly acuminate. The adaxial surface of the leaves is glabrous and the abaxial surface is pubescent. Leaves are characterized by glands absence and are grouped around a branch to which they are inserted through a very short petiole (4-5 $\mathrm{mm}$ in length). The abaxial leaf epidermis is heavily covered with very thick-walled two-armed hairs. Flowers are bisexual, white, small, solitary or in small clusters (Fig. 2). The calyx consists of 4-5 sepals, the corolla with 4-5 petals, and the androecium with five stamens. Within the gynoecium, the style is simple, erect with a very inconspicuous stigma. The ovary is superior with the outer wall heavily covered with hairs. Fruit is an ovoid to oblong berry (Figs. 3

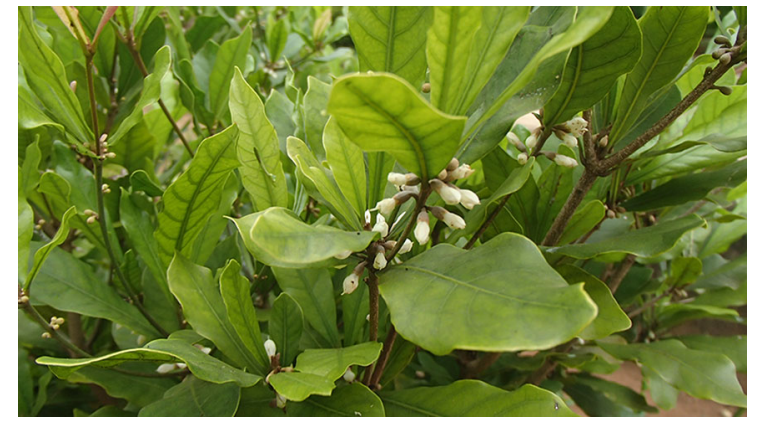

Fig. 2 Synsepalum dulcificum flowers (Sèhouè, Benin)

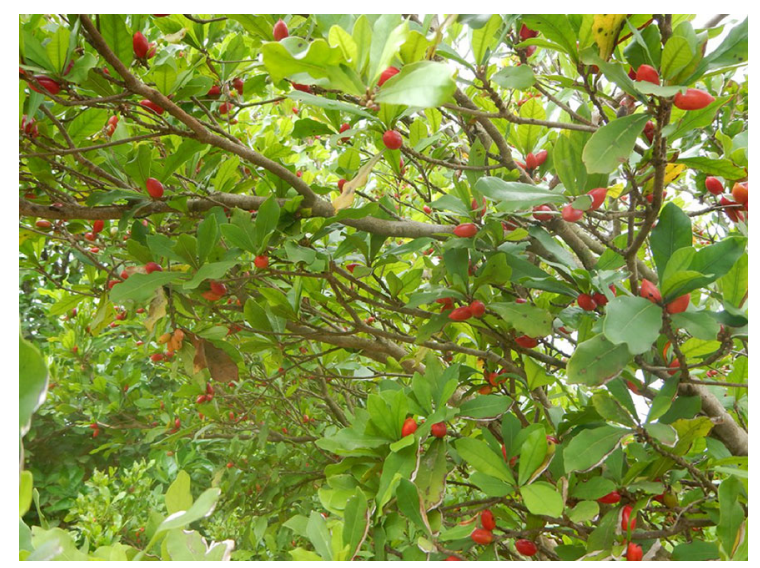

Fig. 3 Synsepalum dulcificum branches bearing ripe fruits (Houéyogbé, Benin)

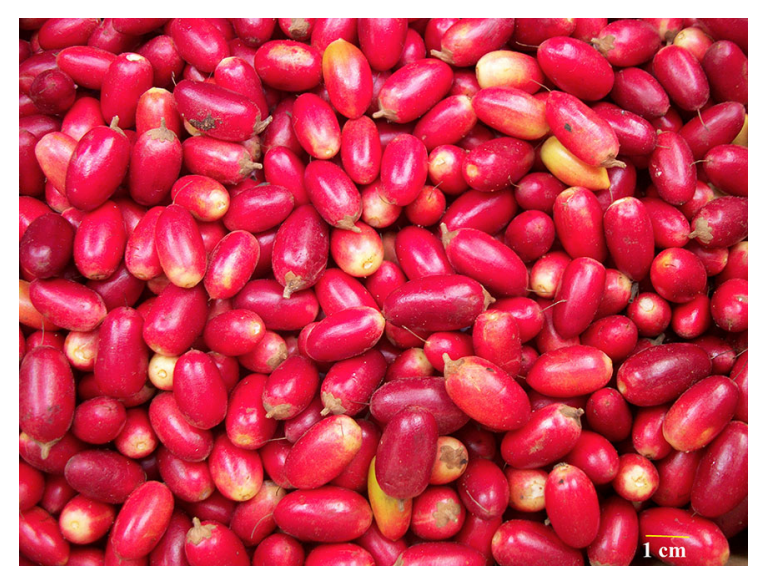

Fig. 4 Oblong ovoid Synsepalum dulcificum berries harvested in Sèhouè, Benin

and 4), 2-2.5 cm long, $1 \mathrm{~cm}$ wide, finely pubescent, with a persistent protruding style, green turning to bright red when ripe (Ayensu 1972; Lim 2013). 


\section{Ecology and distribution}

The miracle fruit is an African native species (Bartoshuk et al. 1974; Huang et al. 2012). Precisely, it originated from west tropical Africa and likely from the country complex consisted of Ghana, Togo, Benin, and Nigeria (Inglett and May 1968). Some characteristics of a plant described in Ouidah $\left(6^{\circ} 21^{\prime} \mathrm{N}, 2^{\circ} 4^{\prime \prime \prime} \mathrm{E}\right)$ since 1724 by travellers in the eighteenth and nineteenth centuries and that are similar to the miracle fruit ones might indicate Benin as the real centre of origin (Juhé-Beaulaton 1998) while Swenson et al. (2008) indicated Ghana as the centre of origin. The species has afterwards been introduced in the USA, Australia, and Asia. The plant behaves well in warm, wet to humid environment, partial shade on welldrained acid substratum with $\mathrm{pH}$ varying from 4.5 to 5.8. The species does not tolerate alkaline conditions and water-logging (Milhet and Costes 1984). In Benin, the species is often cultivated in home gardens and fields in southern Benin (Akoègninou et al. 2006).

Biology and reproductive systems

\section{Reproductive biology}

Scientific literature on the type of pollination for $S$. dulcificum is scarce. However, flowers are hermaphrodite and the species is certainly autogamous. Crosspollination is also possible as well. Knowledge on floral biology and pollination are of paramount importance for breeding; and for S. dulcificum more data are needed. In some other economically important fruit species such as Anacardium occidentale L., Musa spp., and Mangifera indica L. pollinators play a crucial role in yield which can be increased by 60-157\% (Abrol 2012). Does $S$. dulcificum need pollinators to increase yield potential? What are those pollinators and in which proportion do they contribute to increase production and fruit quality? Answers to these questions are prerequisite to successful breeding programmes.

\section{Propagation}

Propagation represents a crucial step in plant breeding. S. dulcificum can successfully reproduce by seed with germination rate reaching up to $80.5 \%$ (Adansi and Hollowey 1977; Oumorou et al. 2010). Regeneration by cutting was reported to be difficult when it comes to rooting (Joyner 2006). Nevertheless, there is a lack of scientific data on the plant growth particularly in nursery and after transplanting. The only report available is of Joyner (2006) who stated that seedling offered faster growth than cutting. According to the same author, cutting is the best propagation way whereby early fruiting can occur.

In in vitro culture Chen et al. (2012) showed that rooting was facilitated when applying indole butyric acid (IBA) at a high concentration (e.g. $800 \mathrm{mg} / \mathrm{L}$ ). Ogunsola and Ilori (2008) have successfully micropropagated the species using embryo in MurashigSkoog medium supplemented with $0.1 \mathrm{mg} / \mathrm{L}$ napthalene acetic acid (NAA) $+0.2 \mathrm{mg} / \mathrm{L}$ 6-benzil-aminopurine (BAP) for culture initiation; with $3.0 \mathrm{mg} / \mathrm{L}$ $\mathrm{BAP}+0.1 \mathrm{mg} / \mathrm{L} \mathrm{NAA}$ for shoot proliferation; and 1.0-2.0 mg/L IBA + 0.1 mg/L BAP for rooting.

Synsepalum dulcificum is therefore propagated either by seed or cutting and also through tissue culture but seedbased regeneration help conserve more variations and provides evolutionary processes through recombination (Jaenicke and Beniest 2002). However, the species exhibits recalcitrant seed storage behaviour (Ogunsola and Ilori 2008) and a successful seed-based propagation must stress on definition of an appropriate storage temperature and duration to prolong seed viability. In Benin, people often use seed to propagate the species. In Australia, the layering of the species has been reported to be successful (Joyner 2006) in contrast to the grafting.

\section{Growth and development}

Synsepalum dulcificum was reported as a slow-growing species. Joyner (2006) distinguished two growth phases. During the first phase corresponding to the first 4 years, the plant grows very slowly reaching about $50 \mathrm{~cm}$ tall. At the second phase, starting from 4-year old, the plant is mature and grows faster. Synsepalum dulcificum's growth is slow compared to other economically important species. For instance, at the same age the height of Vitellaria paradoxa, another species of the same family, is four times that of $S$. duclcificum (Kelly et al. 2004). In west Africa, especially in Benin, where the species is found in home gardens or integrated in agroforestry system involving Persea americana Mill., Mangifera indica L., and Irvingia gabonensis (Aubry-Lecomte ex O'Rorke) Baill., it reaches $5 \mathrm{~m}$ tall (Oumorou et al. 2010). 
Synsepalum dulcificum is an evergreen species which flowers and fruits throughout the year. However, the phenological phases (e.g. growth duration, flowering time, fruiting time, maturation time) need further investigation to complete previous investigation by Oumorou et al. (2010) who reported that flowering and fruiting occur two to three times per year. According to that report the species flowers from April to May, July to August, and from November to December and fruits are available in May, August, October, and from December to February (Oumorou et al. 2010). When, there is no disturbance (e.g. wind, birds, and overexploitation by human), stands bear mature fruit for 30-60 days.

\section{Production and yield}

There is no information on large-scale productions of S. dulcificum in Benin and even in the sub-region; consequently rigorous statistics on yield and production are lacking. Production is exclusively provided by individual stands in home garden and some spare wild stands at farm. Based on our own measurements, such stands can yield $4-5 \mathrm{~kg} /$ fructification, resulting in around $12-15 \mathrm{~kg}$ per year. This yield can vary with the plant age, branching, and habitat. Although there is information about the international trade of fruits on the internet, there are almost no statistics from the international markets and quantities involved in the transactions.

Nutrients content, phytochemical properties and medicinal uses

\section{Nutrients content}

Huang et al. (2012) indicated that $S$. dulcificum is a good source of nutrients and reported that a mixture with Carica papaya, Averrhoa carambola L., and Cucurbita maxima Duchesne fruits powder contained $42.12 \%$ of total sugar, $1.97 \%$ of crude fat, $0.33 \%$ of protein and $11.31 \%$ of water whereas that mixing contents in $\mathrm{K}, \mathrm{Ca}$, and $\mathrm{Mg}$ were respectively $5.926 \mathrm{mg} / \mathrm{g}, 0.826 \mathrm{mg} / \mathrm{g}$ and $0.6 \mathrm{mg} / \mathrm{g}$. Similarly, Guney and Nawar (1977) indicated S. dulcificum has high lipid content. Analysis of the total lipids of the crush seed revealed the presence of neutral lipids $(90.8 \%)$, glycolipids $(7.3 \%)$ and phospholipids $(3.16 \%)$ as primary fractions. Under thin-layer chromatography (TLC), the secondary fraction resulting from glycolipids consisted of monogalactosyl diglyceride $(32.5 \%)$, digalactosyl diglyceride $(20.0 \%)$, and cerebrosides $(39.0 \%)$. Coumpounds of the neutral lipids include triglycerides (75\%), diglycerides $(16 \%)$, monoglycerides $(1.9 \%)$, free fatty acids $(2.9 \%)$ and unsaponifiable material $(1.6 \%)$ whereas the phospholipid fraction consisted of phosphatidyl ethanolamine (32\%), phosphatidyl choline (68\%), and phosphatidyl inositol (4\%) in addition to trace of lysophosphatidyl choline. The fatty acid content of those crushed seed lipid primary fractions is presented in Table 1. Analysis of fatty acids content showed that $S$. dulcificum seed is as rich as Elaeis guineensis (Guney and Nawar 1977) for palmitic acid content. More recently, Nkwocha (2014) provided new data on the nutritional status of the pulp and revealed that $S$. dulcificum pulp is an important source of vitamin C, calcium as well as iron (Table 2). Based on those nutrients contents, $S$. dulcificum is a higher source of vitamin $\mathrm{C}$ when compared to Averrhoa carambola (Edem et al. 2008) and has a chromium content $(0.01 \mathrm{ppm})$ that secures its consumption as this is fivefold lower than the threshold values $(0.05 \mathrm{ppm})$ permitted by the World Health Organization.

The taste modifying property of the miracle fruit is attributed to a glycoprotein named "miraculin" (Inglett et al. 1965). The glycoprotein is characterized by a molecular weight ranging from 24,000 to 45,000 Dalton and consisted of sugars (glucosamine, mannose, fucose, xylose, and galactose), nitrogen, carbohydrates, and nearly 191 amino acids (Lim 2013). However, the action mechanism of that protein is still debated. Two hypotheses are commonly revealed as either subtractive or additive action (Bartoshuk et al. 1974). The subtractive mechanism suggested a paralyzing effect of the miracle fruit throughout sour receptors sites blocking, in such a way that the taste perceived for a substance essentially depends on the taste quality induced by its anion (Dzendolet 1969). In opposite, the miracle fruit is thought to simply add sweetness to sour substances (Kurihara and Beidler 1969). The glycoprotein of miracle fruit binding to the taste cell membrane is unable to link to sugar sensitive receptor sites. Under acid stimuli, the earlier sugar sensitive receptors sites are altered then allowing sugar groups of the glycoprotein to bind to them. In such a taste mixture, the sourness of acid substance is 
Table 1 Fatty acid composition of $S$. dulcificum's fruit seed lipid primary fraction (weight \%) (Guney and Namar 1977)

\begin{tabular}{lcccc}
\hline Fatty acids & Neutral lipids & Glicolipids & Phospholipds & Free fatty acids \\
\hline Lauric acid & 0.3 & 0.9 & 1.4 & 2.6 \\
Myristic acid & 0.6 & 0.2 & 0.2 & 0.4 \\
Pentadecanoic acid & 1.4 & 1.1 & 1.7 & 1.9 \\
Palmitic acid & 37.1 & 28.3 & 23.1 & 23.3 \\
Stearic acid & 6.4 & 5.5 & 2 & 2.3 \\
Oleic acid & 35.7 & 20.3 & 43.8 & 29.7 \\
Linoleic acid & 17.4 & 29.1 & 27.1 & 31.6 \\
Linolenic acid & 0.9 & 14.6 & 0.7 & 4.5 \\
Arachidic acid & 0.1 & - & - & 3.8 \\
\hline
\end{tabular}

Table 2 Nutrients content of S. dulcificum's flesh (Nkwocha 2014)

\begin{tabular}{lr}
\hline Components & Values \\
\hline Ash (\%) & 4.36 \\
Carbohydrates (\%) & 18.84 \\
Crude fat (\%) & 3.26 \\
Crude fibre (\%) & 6.24 \\
Moisture (\%) & 59.55 \\
Protein (\%) & 7.75 \\
Vitamins (\%) & \\
Vit A & 0.04 \\
Vit C & 22.69 \\
Vit D & 0.01 \\
Vit K & 0.02 \\
Minerals (ppm) & \\
Calcium & 100 \\
Chromium & 0.01 \\
Cobalt & 0.01 \\
Copper & 6.22 \\
Iron & 24.2 \\
Zinc & 9.49 \\
\hline
\end{tabular}

reduced or even overlaid. The inversion activity started at the thresholds of $1 \mu \mathrm{M}$ miraculin where $20 \mathrm{mM}$ citrate corresponds to the sweetness of $300 \mathrm{mM}$ sucrose (Matsuyama et al. 2009).

\section{Phytochemical properties and medicinal uses}

The miracle fruit is an important source of phytochemicals. All plant parts are phytochemical-rich. The fruit is a source of miraculin that is effective in controlling human obesity when orally administered at a concentration of 10-7 M. The miraculin can also be used either in solid or liquid form in pharmaceutical industries (Henkin and Giroux 1974). The fruit is also a natural source of ficumone $\left(\mathrm{R}^{*}\right)$-4-hydroxy-2oxetanone (Longchamp 1977), a clear oil which in the past was synthetically prepared (Hanessian and Girard 1994). The methanolic extract of the root revealed the presence of $\mathrm{N}$-trans-feruloyltyramine, $\mathrm{N}$-cis-feruloyltyramine, N-trans-feruloylmethoxytyramine, N-cis-feruloylmethoxytyramine, p-Hydroxybenzoic acid, methylparaben, vanillic acid, isovanillic acid and syringic acid (Chen et al. 2010). P-hydroxybenzoic acid and paraben are synergetic with enterocin KP to inhibit activities of Staphylococcus aureus, Escherichia coli, and Salmonella typhimurium in food (Yildirim et al. 2014) whereas vanillic acid is reported to have protective antioxidant activity when applied at high rate (Masson 2014). Through chromatographic separation, the methanolic extract of $S$. dulcificum leaves revealed presence of eight compounds including a mixture of $\beta$-sitosterol and stigmasterol, pheophytin-a, pheophytin-b, lupeol, lupenone, lupeol acetate, and $\alpha$-tocopheryl quinone among which major ones are beneficial for health. For instance "lupeol" is reported to exhibit antiprotozoal, anti-inflammatory, anticarcinogenic, cardioprotective, antimicrobial, and hepatoprotective activities (Singh et al. 2014). Similarly, the methanolic extract of the stem was reported to contain six pure compounds namely: propane-1,2,3-triol; 2,5-dimethoxyphenol; 3,4,5-trimethoxybenzoic acid; nicotinic acid; $\beta$-sitosterol, and stigmasterol (Cheng et al. 2012). Those phytochemicals, especially for $\beta$-sitosterol, and stigmasterol, exhibit anti-inflammatory, antineoplastic, antipyretic and immuno-modulating activity in animal (Sharma et al. 2014). 
Synsepalum dulcificum stem is the only natural source of 2,5-dimethoxyphenol (Cheng et al. 2012). Based on a spectroscopic analysis, Wang et al. (2011) identified from the stem 13 bioconstituents including: dihydro-feruloyl-5-methoxytyramine; $\quad(+)$-syringaresinol, (+)-epi-syringaresinol, 4-acetonyl-3,5dimethoxy-p-quinol, cis-p-coumaric acid, trans-pcoumaric acid, p-hydroxybenzoic acid, syringic acid, vanillic acid, veratric acid, $\mathrm{N}$-cis-feruloyltyramine, N-trans-feruloyltyramine, and N-cis-caffeoyltyramine. From those compounds, (+)-syringaresinol and $(+)$-epi-syringaresinol were reported to have anti-aging and anti-oxidative activities and to inhibit human skin cancer cells. Similarly, (+)-epi-syringaresinol, 4-acetonyl-3,5-dimethoxy-p-quinol, cisp-coumaric acid, trans-p-coumaric acid, p-hydroxybenzoic acid, vanillic acid, and N-cis-feruloyltyramine by reducing mushroom tyrosinase activity have a great potential to inhibit melanin synthesis and then can be used in hyper-pigmentation treatment. Major anthocyanin compounds include red pigments such as cyanidin-3-monogalactoside, cyanidin-3monoglucoside, cyanidin-3-monoarabinoside, delphinidin-3-monogalactoside and delphmidin-3monoarabinoside and yellow pigments (flavonols) such as quercetin-3-monogalactoside, kaempferol-3monoglucoside, and myricetin-3-monogatactoside (Buckmire and Francis 1976). Red pigments are used as food colorant.

The phytochemicals richness in S. dulcificum was recently confirmed by Du et al. (2014). According to the authors the miracle berry is also an important source of phenolic and flavonoids with metabolites content varying along with the plant parts used. The total phenolic content is significantly higher in fruit flesh (1448.3 mg GA Equiv/100 g) than in the seed $(306.7 \pm 44.1 \mathrm{mg} \mathrm{GA}$ Equiv/100 $\mathrm{g}$ fresh weight)) and the total flavonoids content is approximately three times higher in fruit flesh $(9.9 \pm 0.5 \mathrm{mg}$ of QR Equiv/ $100 \mathrm{~g}$ fresh weight) than in the seeds. Total phenolic and flavonoid content are two widely used antioxidant capability indicators ( $\mathrm{Xu}$ 2012). In addition to its high ascorbic acid content, a total of nine phenolic acids, three anthocyanins, three tocopherols and one carotenoid were identified in the fruit flesh (Table 3) showing that $S$. dulcificum is qualitatively as well as quantitatively more rich in phytochemical compare with others antioxidant-rich berries such as Vaccinium corymbosum L., Rubus fruticosus L., or Fragaria spp.
Table 3 Phytochemical content of S. dulcificum's flesh (Du et al. 2014)

\begin{tabular}{lc}
\hline Compounds & $\begin{array}{l}\text { Concentrations } \\
(\mathrm{mg} / 100 \mathrm{~g} \text { fresh weight })\end{array}$ \\
\hline Vitamins & $28.9 \pm 0.9$ \\
Ascorbic acid & \\
Phenol acids & $17.8 \pm 0.3$ \\
Epicatechin & $10.7 \pm 0.2$ \\
Gallic acid & $5.8 \pm 0.1$ \\
Ferrulic acid & $3.3 \pm 0.2$ \\
Syringenic acid & $2.8 \pm 0.1$ \\
Rutin & $1.1 \pm 0.1$ \\
Quercetin & $0.8 \pm 0.1$ \\
Myricetin & $0.4 \pm 0.0$ \\
Ellagic acid & $0.3 \pm 0.0$ \\
Kaempferol & \\
Anthocyanins & $0.8 \pm 0.1$ \\
Delphinidin glucoside & $2.6 \pm 0.1$ \\
Cyanidin galactoside & $10.1 \pm 0.7$ \\
Malvidin galactoside & \\
Carotenoids & $0.4 \pm 0.0$ \\
Lutein & $5.8 \pm 0.3$ \\
$\alpha$-Tocopherol & $0.6 \pm 0.1$ \\
$\alpha$-Tocotrienol & $1.0 \pm 0.1$ \\
\hline & \\
\hline & \\
\hline
\end{tabular}

(Du et al. 2014). Furthermore, an ABT (2, 20-azinobis (3-ethyl-benzothiazoline-6-sulfonic acid)) assay revealed effectiveness of the miracle fruit flesh extract in inhibiting toxic lipid oxidation production. Owing to those properties, the flesh extract of $S$. dulcificum could be a suitable alternative to synthetic food antioxidants and by the same way prevent from chronic diseases associated with lipid metabolism problem. In investigating $S$. dulcificum effects on the induced insulin resistance, Chen et al. (2006) showed that the species fruit powder has the ability to improve insulin sensitivity and could thus be of importance in diabetic patients treatment or serve as alternative sugar for diabetic patients. Another interest in this natural sweetener is the prevention of carcinogenesis risks that are associated to artificial sweeteners such as cyclamates and saccharin (IARC 1980). Similarly, in a mice-based model, it has been showed that when mixed with Averrhoa carambola L., Carica papaya L. and Cucurbita maxima Duchesne fruit powders and suitably orally administered, S. dulcificum fruit 
powder exhibited anti-fatigue properties as well as an improvement of immune function (Huang et al. 2012).

Prospects and research avenues

\section{Genetic resources, eco-geographical distribution} of genotypes and conservation

Genetic resources of $S$. dulcificum are almost absent in international genebanks and even in national genebanks of countries of origin of the species. This is a serious drawback for breeding programmes when it comes to improve varieties. In Ghana, the Plant Genetic Resources Research Institute (PGRRI) hold living collections of $S$. dulcificum conserved in wildrelative plantings and in Botanical garden (Houssou 2014). The National Center for Biotechnology Information (NCBI) hold fifteen nucleotide accessions of $S$. dulcificum including DNA sequence from plastid, chloroplast gene and an ARN sequence (Table 4).

Moreover, the species is said to be often cultivated (Akoègninou et al. 2006; Idohou et al. 2013) which implies the existence of three categories of genotype sources: wild stands, home gardens populations and cultivated farms. However, knowledge on wild populations is scanty. This situation opens a room for wider collection of genetic resources and definition of areas of diversity. Analysis of ecological and geographical distribution of genetic diversity based on molecular tools (e.g. AFLP and SNP) would help increase knowledge on potential sites for genetic diversity.

A good conservation of S. dulcificum is essential for sustainable utilization. In its current state, S. dulcificum is frequently found in home gardens (Fig. 1b) where it benefits of cares from owners. Home garden has been reported as an important hotspot of genetic resources conservation and diversity (Galluzzi et al. 2010; Pintureau 2006). For instance, home gardens were reported to conserve over 60 plant species in Ghana (Caussanel 1989), 59 Phaseolus lunatus L. landraces in Cuba (Castiñeiras et al. 2007) and 29 Pyrus communis L. landraces in Italy. Predominance of fruit trees characterized specific richness of home gardens, especially when these latter are source of fibers or vitamins (Mitchell and Hanstad 2004). Home gardens represent an important and a sustainable conservation measure for $S$. dulcificum as the species exhibit recalcitrant seed storage behaviour. S. dulcificum is also conserved on-farm and spared during land clearing (Fig. 1a). However, this is threatened by either shifting agriculture or deforestation or by growing urbanization; hence the need not only to set adequate $e x$ situ conservation strategies such as living collections, in vitro conservation (using slow growth methods), cryopreservation of shoot tips or seed germ among other methods but also to investigate determinants of the species conservation and production and finally to produce reliable statistics on the species.

\section{Morphological and molecular characterization and evaluation of genotypes}

To the best of our knowledge there is no information on the genetic diversity and structure in S. dulcificum. This situation offers room for increased investigation on germplasm characterization and evaluation. Genotypes characterization is a crucial step in all breeding program (Grüneberg et al. 2009). A prior morphological and biochemical analyses will path way for molecular genetic studies and accelerate traits discovery and selection of best cultivars. For instance, morphological characterization is necessary to assess intraspecific partition of genotypes and how variation of traits is independent of environmental changes. It will thoroughly inform on yield potential (e.g. maturity time, fruit size, number of fruiting season per year, individual plant production, sugar and secondary metabolites content) and how this is related to intraspecific variation. Moreover, the species might be present in the wild (Bleasdale 1959) but is often cultivated (Akoègninou et al. 2006). However, domestication processes by humans such as selection, translocation and cultivation are known to affect the morphological and genetic diversity of tree species (Pintureau 2006). Therefore, knowledge of the association between plant and fruit traits and genetic diversity patterns among wild and cultivated populations could help assess possible loss of intra-specific diversity after domestication by comparing the genetic diversity of sub-populations to identify hotspot and priority areas of conservation. There are also opportunities to evaluate germplasm against environmental stress (biotic and abiotic) and effects on nutrients and metabolites content. Multilocal field trials will be adequate to determine appropriate production environments in tropical Africa. Elements to be considered include for instance soil types, rainfall ranges 
Table 4 Genebank sequence data of Synsepalum dulcificum (http://www.ncbi.nlm.nih.gov/)

\begin{tabular}{|c|c|c|c|c|}
\hline $\begin{array}{l}\text { Accession } \\
\text { number }\end{array}$ & $\begin{array}{l}\text { Sequence } \\
\text { type }\end{array}$ & $\begin{array}{l}\text { Size } \\
(\mathrm{bp})\end{array}$ & Source & Description \\
\hline DQ344211 & $\begin{array}{l}\text { Genomic } \\
\text { DNA }\end{array}$ & 824 & Plastid:chloroplast & $\begin{array}{l}\text { Synsepalum dulcificum rpl20-rps12 intergenic spacer, partial sequence; } \\
\text { chloroplast }\end{array}$ \\
\hline AB512278 & $\begin{array}{l}\text { Genomic } \\
\text { DNA }\end{array}$ & 663 & - & Synsepalum dulcificum RdMIR gene for miraculin, complete cds \\
\hline AB622419 & $\begin{array}{l}\text { Genomic } \\
\text { DNA }\end{array}$ & 217 & - & Synsepalum dulcificum DNA, SINE:Au SINE, complete sequence \\
\hline AB622420 & $\begin{array}{l}\text { Genomic } \\
\text { DNA }\end{array}$ & 212 & - & Synsepalum dulcificum DNA, SINE:Au SINE, complete sequence \\
\hline AB622421 & $\begin{array}{l}\text { Genomic } \\
\text { DNA }\end{array}$ & 210 & - & Synsepalum dulcificum DNA, SINE:Au SINE, complete sequence \\
\hline DQ344446 & $\begin{array}{l}\text { Genomic } \\
\text { DNA }\end{array}$ & 752 & Plastid:chloroplast & $\begin{array}{l}\text { Synsepalum dulcificum trnS-trnG intergenic spacer, partial sequence; } \\
\text { chloroplast }\end{array}$ \\
\hline DQ344274 & $\begin{array}{l}\text { Genomic } \\
\text { DNA }\end{array}$ & 770 & Plastid:chloroplast & $\begin{array}{l}\text { Synsepalum dulcificum psbB gene, partial sequence; psbN gene, complete } \\
\text { sequence; and psbH gene, partial sequence; chloroplast }\end{array}$ \\
\hline DQ344337 & $\begin{array}{l}\text { Genomic } \\
\text { DNA }\end{array}$ & 970 & Plastid:chloroplast & $\begin{array}{l}\text { Synsepalum dulcificum tRNA-Leu and trnL-trnF intergenic spacer, partial } \\
\text { sequence; chloroplast }\end{array}$ \\
\hline DQ344148 & $\begin{array}{l}\text { Genomic } \\
\text { DNA }\end{array}$ & 520 & Plastid:chloroplast & $\begin{array}{l}\text { Synsepalum dulcificum trnH-psbA intergenic spacer, partial sequence; } \\
\text { chloroplast }\end{array}$ \\
\hline DQ377538 & $\begin{array}{l}\text { Genomic } \\
\text { DNA }\end{array}$ & 754 & Plastid:chloroplast & $\begin{array}{l}\text { Synsepalum dulcificum rbcL-atpB intergenic spacer, partial sequence; } \\
\text { chloroplast }\end{array}$ \\
\hline DQ246697 & $\begin{array}{l}\text { Genomic } \\
\text { DNA }\end{array}$ & 715 & - & $\begin{array}{l}\text { Synsepalum dulcificum } 18 \mathrm{~S} \text { ribosomal RNA gene, partial sequence; internal } \\
\text { transcribed spacer } 1,5.8 \mathrm{~S} \text { ribosomal RNA gene, and internal transcribed } \\
\text { spacer } 2 \text {, complete sequence; and } 28 \mathrm{~S} \text { ribosomal RNA gene, partial } \\
\text { sequence }\end{array}$ \\
\hline HQ158591 & $\begin{array}{l}\text { Genomic } \\
\text { DNA }\end{array}$ & 974 & Plastid:chloroplast & $\begin{array}{l}\text { Synsepalum dulcificum tRNA-Leu (trnL) gene, partial sequence; trnL-trnF } \\
\text { intergenic spacer, complete sequence; and tRNA-Phe (trnF) gene, partial } \\
\text { sequence; chloroplast }\end{array}$ \\
\hline HQ158554 & $\begin{array}{l}\text { Genomic } \\
\text { DNA }\end{array}$ & 833 & Plastid:chloroplast & $\begin{array}{l}\text { Synsepalum dulcificum AtpB (atpB) gene, partial cds; atpB-rbcL intergenic } \\
\text { spacer, complete sequence; and ribulose-1,5-bisphosphate carboxylase/ } \\
\text { oxygenase large subunit (rbcL) gene, partial cds; chloroplast }\end{array}$ \\
\hline GQ141118 & mRNA & 504 & - & $\begin{array}{l}\text { Synsepalum dulcificum MADS-domain transcription factor (GLO) mRNA, } \\
\text { partial cds }\end{array}$ \\
\hline GQ141179 & $\begin{array}{l}\text { Genomic } \\
\text { DNA }\end{array}$ & 558 & - & $\begin{array}{l}\text { Synsepalum dulcificum MADS-domain transcription factor (DEF) gene, } \\
\text { partial cds }\end{array}$ \\
\hline AY230739 & $\begin{array}{l}\text { Genomic } \\
\text { DNA }\end{array}$ & - & Plastid:chloroplast & - \\
\hline
\end{tabular}

required, irrigation systems, day length, temperatures, and relative humidity.

The plant part that is of interest when it comes to application in food and drug sweetening is the pulp. However, up to now, very little is known about how nutrient content of the pulp is affected by environmental factors. Thus, studies of the variation of the nutrient content of the species across ecological gradients are welcome.
Genotypes improvement for beverages, cosmetics and pharmaceutical industries

The utilization of secondary metabolites of $S$. dulcificum in beverage and food coloring and stabilization offers new market opportunities. However, the effect of environmental variation for instance on miraculin content need to be investigated and genotypes selected accordingly. 
Synsepalum dulcificum also has potential in pharmaceutical industries as indicated above. In that line, using the glycoprotein properties to reduce the bitter taste of some drugs could facilitate their ingestion while the numerous phytochemical could be important source of active substances in pharmacy. There is then a need to improve genotypes for a better phytochemical and glycoprotein content. Cosmetic industries could also explore possibility of a better exploitation of stem bio-constituents such as (+)syringaresinol and (+)-epi-syringaresinol.

In these regards molecular breeding is an avenue for rapid selection of lines. Largely adopted in breeding of crops such as Musa sapientum L., Persea americana Mill., Cucumis sativus L., and Citrus spp., molecular assisted selection has facilitated identification of genes associated to traits of interest. Current knowledge on molecular breeding of S. dulcificum is scanty; yet rapid identification of genes associated to resistance to various stresses, the miraculin content and secondary metabolites content is desired.

\section{Improving asexual reproduction}

The time to first fruiting of $S$. dulcificum regenerated from seeds is estimated at $4-5$ years. For such an economically important fruit species, reducing the length of that cycle should increase benefits. Vegetative propagation enabled capture and fixation of interesting traits, of individual trees (Simons and Leakey 2004). The importance of vegetative propagation in early fruiting was reported and can be exploited. To the best of our knowledge, no improvement strategies have been developed up to now to shorten the breeding cycle of $S$. dulcificum except some propagation attempts using stem cutting and tissue culture (Chen et al. 2012; Ogunsola and Ilori 2008). Though difficult to root, cutting is successful when assisted with indole butyric acid application. It is also known that cutting rooting ability is influenced by the cutting's volume (Leakey and Akinnifesi 2008). In this regards, testing the effect of $S$. dulcificum stem cutting size (length, diameter) combined to rooting hormone could be investigated so as to reduce the time to fructification and develop early maturing varieties. In this process, the inherent characteristics of the stockplant are key for expression of clone potential. Because the use of either juvenile or mature tissues has their respective advantages (Leakey and Akinnifesi 2008), testing the two plant materials in the vegetative propagation could provide further insight into improving genotypes. Although there is crucial lack of scientific evidence on production cycle reduction from stem cuttings, we should be aware that seedlings have been grown from cuttings in Miami, with one-year old plants bearing fruits (http://miraclefruitfarm.com/ shop/10-plants-with-fruit-shipping-included). Vitellaria paradoxa C. F. Gaertn., another economically important species of the same family has been successfully improved through cutting from hardwood, softwood and coppice shoots (Kalinganire et al. 2008).

Another interesting vegetative propagation technique is grafting. Compared to cutting, grafting enables earlier fruit production and damaged cells repair (Hartmann et al. 1997). In Vitellaria paradoxa grafting has been reported to reduce from 20 to 6 years the age of first fruiting (Kalinganire et al. 2008). Likewise, Sanou et al. (2004) showed that fruiting period can still be reduced when the grafting technique and period are adequately chosen. They reported that grafts have produced fruits after 2 years with side veneer grafting method and the grafting set in May.

\section{Conclusion}

Synsepalum dulcificum is a useful plant resource that could help alleviate poverty. It has many benefits for local populations and a great potential in food and drug industries. The species is used as fruit and also in medicine, cosmetics, food and pharmaceutical industries. However, the sustainable use of genetic resources is hypothetical if nothing is done. At present, knowledge on the biology of the species, the current conservation status, and intra-specific variations is narrow. Also, genetic and environmental factors affecting interesting traits are poorly documented. To promote the sustainable use of $S$. dulcificum we suggest to deepen knowledge on horticultural practices for increased fruit production, developing lines for beverages, cosmetics and pharmaceutical industries, and ensuring ex situ and in situ conservation of genetics resources.

\section{References}

Abrol DP (2012) Pollination-basic concepts. In: Abrol DP (ed) Pollination Biology. Springer, Berlin, pp 37-54 
Adansi MA, Hollowey HLO (1977) Germination of seeds of the sweet or miraculous berry Synsepalum dulcificum Daniell. Acta Hortic 53:181-182

Akoègninou A, Van der Burg WJ, Van der Maesen LJG (2006) Flore Analytique du Bénin. Backhuys Publishers, Wageningen

Ayensu ES (1972) Morphology and anatomy of Synsepalum dulcificum (Sapotaceae). Bot J Linn Soc 65:179-187

Bartoshuk LM, Gentile RL, Moskowitz HR, Meiselman HL (1974) Sweet taste induced by miracle fruit (Synsepalum dulcificum). Physiol Behav 12:449-456

Bleasdale JKA (1959) Studies on plant competition. Blackwell, Oxford

Buckmire R, Francis F (1976) Anthocyanins and flavonols of miracle fruit, Synsepalum dulcificum Schum. J Food Sci 41:1363-1365

Buckmire RE, Francis FJ (1978) Pigments of miracle fruit, Synsepalum dulcificum Schum, as potential food colorants. J Food Sci 43:908-911

Burkill MH (2000) The useful plants of West Tropical Africa, vol 5. Families S-Z Cryptogams Addenda, Royal Botanical Gardens

Cakmak I (2008) Enrichment of cereal grains with zinc: agronomic or genetic biofortification? Plant Soil 302:1-17

Candolle AD (1844) Sideroxylon dulcificum. Prodromus Syst Nut Veg 8:183

Castiñeiras L, Guzmán FA, Duque MC, Shagarodsky T, Cristóbal R, De Vicente MC (2007) AFLPs and morphological diversity of Phaseolus lunatus L. in Cuban home gardens: approaches to recovering the lost ex situ collection. Biodivers Conserv 16:2847-2865

Caussanel JP (1989) Nuisibilité et seuils de nuisibilité des mauvaises herbes dans une culture annuelle: situation de concurrence bispécifique. Agronomie 9:219-240

Chen CC, Liu IM, Cheng JT (2006) Improvement of insulin resistance by miracle fruit (Synsepalum dulcificum) in fructose-rich chow-fed rats. Phytotherapy 20:987-992

Chen CY, Wang YD, Wang HM (2010) Chemical constituents from the roots of Synsepalum dulcificum. Chem Nat Comp 46:448-449

Chen XW, Abdullah TL, Abdullah NAP, Hassan SA (2012) Rooting response of miracle fruit (Synsepalum dulcificum) softwood cuttings as affected by indole butyric acid. Am J Agric Biol Sci 7:442-446

Cheng M-J, Hong Z-L, Chen CY (2012) Secondary metabolites from the stem of Synsepalum dulcificum. Chem Nat Comp 48:108

Du L, Shen Y, Zhang X, Prinyawiwatkul W, Xu Z (2014) Antioxidant-rich phytochemicals in miracle berry (Synsepalum dulcificum) and antioxidant activity of its extracts. Food Chem 153:279-284

Dzendolet E (1969) Theory for the mechanism action of miracle fruits. Percept Psycophys 6:187-188

Edem CA, Dosunmu MI, Ebong AC, Jones M (2008) Determination of proximate composition of ascorbic acid and heavy metal content of star fruit (Averrhoa carambola). Glob J Pure Appl Sci 14:193-195

Gaikwad KB, Singh N, Bhatia D, Kaur R, Bains NS, Bharaj TS, Singh K (2014) Yield-Enhancing Heterotic QTL Transferred from wild species to cultivated rice Oryza sativa L. PLoS One 9:e96939
Galluzzi G, Eyzaguirre P, Negri V (2010) Home gardens: neglected hotspots of agro-biodiversity and cultural diversity. Biodivers Conserv 19:3635-3654

Grüneberg W, Mwanga R, Andrade M, Espinoza J, Ceccarelli S, Guimarães E, Weltzien E (2009) Selection methods. Part 5: breeding clonally propagated crops. In: Ceccarelli S, Guimarães E, Weltzien E (eds) Plant breeding and farmer participation. FAO, Rome, p 275

Guney S, Nawar WW (1977) Seed lipids of the miracle fruit. J Food Biochem 1:173-184

Hanessian S, Girard C (1994) Facile access to 3-ulosonic acids via a SmI2-mediated reformatskii reaction on aldonolactones. Synlett 67:868

Hartmann HT, Kester DE, Davies FT, Geneve RL (1997) Propagation by specialized stems and roots, 6th edn. Prentice Hall, New Jersey

Henkin RI, Giroux EL (1974) Purification and some properties of miraculin, a glycoprotein from Synsepalum dulcificum which provokes sweetness and blocks sourness. J Agric Food Chem 22:595-601

Houssou M (2014) Assessment of means and facilities for plant genetic resource management and development in West and Central Africa. Cooperating to make the best use of plant genetic resources in West and Central Africa: a regional imperative bioversity international, Rome, Italy and CORAF/WECARD, Dakar, Senegal: 59

Huang J-B, Liu H, Qi H-L, Lu S-L (2012) Anti-fatigue and immune function by nutritional constituents from Synsepalum dulcificum mixing fruit power [J]. Chin J Exp Tradit Med Formul 14:058

IARC (1980) Sorne non-nutritive sweetening agents, vol 22. WHO, Lyon

Idohou R, Assogbadjo AE, Fandohan B, Gouwakinnou GN, Kakai RLG, Sinsin B, Maxted N (2013) National inventory and prioritization of crop wild relatives: case study for Benin. Genet Resour Crop Evol 60:1337-1352

Inglett GE, May JF (1968) Tropical plants with unusual taste properties. Econ Bot 22:326-331

Inglett GE, Dowling B, Albrecht JJ, Hoglan FA (1965) Tastemodifying properties of miracle fruit (Synsepalum dulcificum). J Agric Food Chem 13:284-287

Jaenicke H, Beniest $\mathbf{J}$ (2002) Vegetative tree propagation in agroforestry training. Principle and references, ICRAF

Jonkers H (1958) Accelerated flowering of strawberry seedlings. Euphytica 7:41-46

Joyner G (2006) The miracle fruit. In: Scott P (ed) Quandong magazine of the west Australian nut and tree crop association. West Australian Nut and Tree Crop Association Subiaco, West Australia, p 15

Juhé-Beaulaton D (1998) "Fèves", "pois" et "grains" dans le golfe de Guinée : problèmes d'identification des plantes dans les sources historiques. In: Chastanet M (ed) Plantes et paysages d'Afrique, une histoire à explorer. Karthala, CRA, pp 45-68

Kalinganire A, Weber J, Uwamariya A, Kone B (2008) Improving rural livelihoods through domestication of indigenous fruit trees in the parklands of the Sahel. In: Akinnifesi FK, Leakey RRB, Ajayi OC, Sileshi G, Tchoundjeu Z, Matakala P, Kwesiga FR (eds) Indigenous fruit trees in the tropics: domestication, utilization and 
commercialization. CAB International, Wallingford, pp 186-203

Kelly BA, Hardy OJ, Bouvet J-M (2004) Temporal and spatial genetic structure in Vitellaria paradoxa (shea tree) in an agroforestry system in southern Mali. Mol Ecol 13:1231-1240

Kurihara K, Beidler LM (1969) Mechanism of action of tastemodifying protein. Nature 222:1176-1179

Leakey RRB, Akinnifesi FK (2008) Towards a domestication strategy for indigenous fruit trees in the tropics. In: Akinnifesi FK, Leakey RRB, Ajayi OC, Sileshi G, Tchoundjeu Z, Matakala P, Kwesiga FR (eds) Indigenous fruit trees in the tropics: domestication, utilization and commercialization. CAB International, Wallingford, pp 28-49

Lim TK (2013) Synsepalum dulcificum. In: Lim TK (ed) Edible medicinal and non-medicinal plants. Springer, Berlin, pp 146-150

Longchamp H (1977) Nuisibilité des mauvaises herbes. Rev Phytoma 288:7-15

Lucca P, Hurrell R, Potrykus I (2001) Genetic engineering approaches to improve the bioavailability and the level of iron in rice grains. Theor Appl Genet 102:392-397

Masson L (2014) Phenolic acids as natural antioxidants. In: Praksh D, Sharma G (eds) Phytochemicals of neutraceutical importance. CAB International, Wallingford, pp 196207

Matsuyama T, Satoh M, Nakata R, Aoyama T, Inoue H (2009) Functional expression of miraculin, a taste-modifying protein in Escherichia coli. J Biochem 145:445-450

Milhet Y, Costes C (1984) Some data on sweetener plants biology. Acta Hortic 144:77-84

Mitchell R, Hanstad T (2004) Small homegarden plots and sustainable livelihoods for the poor. LSP Working paper. Food and agriculture organization of the United Nations, Rome

Nkwocha C (2014) Proximate and composition analyses of Synsepalum dulcificum pulp. Sci Res J 2:71-74

Ogunsola KE, Ilori CO (2008) In vitro propagation of miracle berry (Synsepalum dulcificum Daniell) through embryo and nodal cultures. Afr J Biotechnol 7:244-248

Oumorou M, Dah-Dovonon J, Aboh BA, Hounsoukaka M, Sinsin B (2010) Contribution à la conservation de synsepalum dulcificum : régénération et importance socioéconomique dans le département de l'ouémé (Bénin). Ann Sci Agron 14:101-120

Pieniazek SA (1976) Natural sweeteners and effects on taste. Natürliche Süssungsmittel und Geschmacksbeeinflussung. Industrielle Obst-und Gemüseverwertung 61:229-231
Pintureau B (2006) Lutte biologique contre les organismes nuisibles à l'agriculture. INRA, France

Ray PK (2002) Papaya. Narosa Publishing House, New Delhi

Sanou H et al (2004) Vegetative propagation of Vitellaria paradoxa by grafting. Agrofor Syst 60:93-99

Schumacher HCF (1827) Blumea dulcificum. Danske Vid. Selsk, Beskrivelse af Guineiske planter

Sharma G, Prakash D, Gupta C (2014) Phytochemicals of neutraceutical importance: do they defend against diseases? In: Prakash D, Sharma G (eds) Phytochemicals of nutraceutical importance. CAB International, Wallingford, pp 1-19

Simons A, Leakey R (2004) Tree domestication in tropical agroforestry. In: Nair PKR, Rao MR, Buck LE (eds) New vistas in agroforestry. Springer, Berlin, pp 167-181

Singh RL, Sharma S, Singh P (2014) Antioxidants: Their health benefits and plant sources. In: Prakash D, Sharma G (eds) Phytochemicals of neutraceutical importance. CAB International, Wallingford, pp 248-265

Stein AJ, Nestel P, Meenakshi J, Qaim M, Sachdev H, Bhutta ZA (2007) Plant breeding to control zinc deficiency in India: how cost-effective is biofortification? Pub Health Nutr 10:492-501

Swenson U, Richardson JE, Bartish IV (2008) Multi-gene phylogeny of the pantropical subfamily Chrysophylloideae (Sapotaceae): evidence of generic polyphyly and extensive morphological homoplasy. Cladistics 24:1006-1031

Tamaki M, Urasaki N, Nakamura I, Motomura K, Adaniya S (2011) Shortening the breeding cycle of papaya (Carica papaya L.) by culturing embryos treated with ethrel. Plant Cell Tiss Org 106:225-233

Tiwari VK, Rawat N, Neelam K, Kumar S, Randhawa GS, Dhaliwal HS (2010) Substitutions of 2 S and 7U chromosomes of Aegilops kotschyi in wheat enhance grain iron and zinc concentration. Theor Appl Genet 121:259-269

Wang H-M et al (2011) Bioconstituents from stems of Synsepalum dulcificum Daniell (Sapotaceae) inhibit human melanoma proliferation, reduce mushroom tyrosinase activity and have antioxidant properties. J Taiwan Inst Chem Eng 42:204-211

$\mathrm{Xu} \mathrm{Z} \mathrm{(2012)} \mathrm{Analysis} \mathrm{methods} \mathrm{of} \mathrm{phenolic} \mathrm{acids.} \mathrm{In:} \mathrm{Xu} \mathrm{Z,}$ Howard LR (eds) Analysis of antioxidant-rich phytochemicals. Wiley, Iowa, pp 69-74

Yildirim Z, Ilk Y, Yildirim M (2014) The synergist effect of p-hydroxybenzoic acid and propyl-paraben on the antibacterial activity of enterocin KP. Turk J Agric Food Sci Technol 2:1-5 